\title{
HUBUNGAN TINGKAT KECEMASAN IBU HAMIL TRIMESTER III DENGAN KESIAPAN MENGHADAPI PERSALINAN PADA MASA PANDEMI COVID 19 DI PRAKTIK MANDIRI BIDAN (PMB)
}

\author{
Ida Suryani, ${ }^{1}$ L'mira Seutiya Wati ${ }^{2}$ \\ ${ }^{1,2}$ Program Studi Diploma Tiga Kebidanan STIKes Dharma Husada Bandung \\ Ida.ardinansyah@gmail.com \\ lmiralmiralmira123@gmail.com
}

\begin{abstract}
ABSTRAK
Kecemasan adalah keadaan perasaan keprihatinan, rasa gelisah, ketidaktentuan, atau takut dari kenyataan atau persepsi ancaman normal terjadi dalam berbagai keadaan, seperti pertumbuhan, adanya perubahan dan pengalaman baru merupakan perasaan takut yang tidak jelas penyebabnya dan tidak didukung oleh situasi yang ada. Kecemasan ibu selama hamil dan menjelang persalianan dapat dipengaruhi oleh faktor usia maupun sosial ekonominya, karena kedua faktor tersebut akan turut menentukan kesiapan ibu dan keluarga dalam menjalani kehamilan serta mempersiapkan proses persalinan. jenis penelitian ini menggunakan analitik observasional dengan desain cross sectional. Jumlah sampel 40 ibu hamil trimester III sesuai dengan kriteria inklusi yaitu ibu hamil trimester 3 bersedia menjadi responden. Teknik sampling dengan purposive sampling. Data dianalisis menggunakan uji chi-square. Hasil penelitian menunjukkan bahwa sebanyak $72.5 \%$ responden memiliki kecemasan ringan dengan kesiapan melahirkan yang baik. Ibu hamil mengalami kecemasan disebabkan oleh pandemi takut terjadi sesuatu hal yang tidak diinginkan. Hasil uji analisis statistic menjelaskan bahwa terdapat hubungan antara tingkat kecemasan ibu hamil trimester 3 dengan kesiapan melahirkan di masa pandemic $(\mathrm{p}=0.005)$.
\end{abstract}

Kata Kunci : Tingkat Kecemasan, Kesiapan persalinan, Kehamilan Trimester 3

\section{PENDAHULUAN}

Kecemasan adalah keadaan perasaan keprihatinan, rasa gelisah, ketidaktentuan, atau takut dari kenyataan atau persepsi ancaman normal terjadi dalam berbagai keadaan, seperti pertumbuhan, adanya perubahan dan pengalaman baru merupakan perasaan takut yang tidak jelas penyebabnya dan tidak didukung oleh situasi yang ada. ${ }^{1}$ Kecemasan tidak dapat dihindarkan dari kehidupan seharihari. Kecemasan dapat dirasakan oleh setiap orang jika mengalami tekanan dan perasaan mendalam yang menyebabkan masalah psikiatrik dan dapat berkembang dalam jangka waktu lama. $^{2}$

Kecemasan merupakan bagian dari respon emosional, dimana ansietas adalah kekhawatiran yang tidak jelas dan menyebar, yang berkaitan dengan perasaan tidak pasti dan tidak berdaya. Keadaan emosi ini tidak memiliki objek yang spesifik. Dimana ansietas dialami cara subjektif dan dikomunikasikan 
secara interpersonal. ${ }^{1}$ Kecemasan ibu selama hamil dan menjelang persalianan dapat dipengaruhi oleh faktor usia maupun sosial ekonominya, karena kedua faktor tersebut akan turut menentukan kesiapan ibu dan keluarga dalam menjalani kehamilan serta mempersiapkan proses persalinan. Begitu pula status graviditas primipara akan lebih tinggi tingkat kecemasannya daripada ibu dengan status multigravida. ${ }^{3}$

Gejala cemas yang timbul berbeda-beda pada setiap individu. Gejala cemas dapat berupa gelisah, pusing, jantung berdebar, gemetaran dan lain sebagainya. Salah satu sumber stressor kecemasan adalah kehamilan, terutama pada ibu hamil yang labil jiwanya. Pada umumnya seorang ibu yang mengalami kehamilan untuk pertama kalinya akan merasa senang dan semakin tinggi rasa ingin tahu terhadap perubahann dirinya dan perkembangan janin. Tetapi disaat yang sama timbul pula rasa cemas dalam diri ibu hamil. ${ }^{4}$

Kehamilan adalah pengalaman yang menimbulkan banyak perubahan psikologis pada wanita hamil. Dalam kehamilan akan terjadi perubahan hormon. Perubahan hormon ini akan mengakibatkan ibu mengalami beberapa perubahan emosional pada trimester I, sedangkan tingkat depresi atau kecemasan selama trimester kedua dan ketiga hampir dua kali lipat dari trimester pertama. ${ }^{5}$ Terdapat empat tingkat kecemasan yaitu kecemasan ringan, kecemasan sedang, kecemasan berat, dan kecemasan sangat berat. Angka kematian kelahiran (AKI) tahun 2014 di Indonesia pada persalinan pervaginam 95-120 per 100.000 kelahiran hidup, sedangkan angka kematian operasi seksio sesarea adalah 112-130 tiap 100.000 kelahiran hidup, melihat besarnya resiko yang mungkin ditimbulkan pada saat persalinan baik operasi seksio sesarea maupun pervaginam, maka hal ini dapat menyebabkan kecemasan pada pasien yang akan menghadapi persalinan. ${ }^{6}$ Hal ini menunjukkan bahwa sebagian besar ibu mengalami kecemasan sedang meskipun usia mereka berada dalam rentang usia reproduksi aman atau sehat. menunjukkan kecemasan lebih banyak dialami pada ibu hamil Primigravida (kehamilan pertama) yaitu sebanyak 66,2\% dibandingkan dengan kecemasan pada ibu hamil Multigravida sebanyak $42,2 \% .^{7} \quad 94 \%$ wanita khawatir mengenai apakah bayi mereka akan normal, 93\% wanita khawatir mengenai apakah meraka dan bayinya akan melewati persalinan dengan selamat dan $91 \%$ wanita khawatir tentang badan mereka ketimbang kesehatan mereka selama kehamilan. ${ }^{8}$

Gejala kecemasan dapat dikelompokkan menjadi beberapa keadaan seperti gelisah, sakit kepala, gemetar, tidak dapat santai, kepala terasa ringan, berkeringat, jantung berdebardebar (palpitasi), sesak nafas, keluhan lambung, pusing, mulut kering, dan sebagainya. ${ }^{8}$ Kecemasan ibu hamil dapat timbul khususnya pada trimester ketiga kehamilan hingga saat persalinan, dimana pada periode ini ibu hamil merasa cemas terhadap berbagai hal seperti normal atau tidak normal bayinya lahir, nyeri yang akan dirasakan dan sebagainya. Semakin 
dekatnya jadwal persalinan, terutama pada kehamilan pertama, wajar jika timbul perasaan cemas atau takut karena kehamilan merupakan pengalaman yang baru. ${ }^{9}$

Kehamilan di era pandemic COVID-19 menyebabkan timbulnya kecemasan tersendiri bagi ibu hamil. berbagai penelitian kebanyakan menyimpulkan bahwa kehamilan menyebabkan tubuh lebih rentan terhadap gejala COVID-19 yang berat karena sistem kekebalan tubuh. ibu hamil memiliki risiko lebih tinggi terhadap terjadinya penyakit berat, morbiditas dan mortalitas dibandingkan dengan populasi umum. Efek samping pada janin berupa persalinan preterm juga dilaporkan pada ibu hamil dengan infeksi COVID-19. ${ }^{10}$

Wanita hamil berisiko untuk memiliki gejala yang berat dibandingkan dengan wanita yang tidak sedang hamil masa kehamilan, persalinan, dan postpartum merupakan masa yang rentang dengan adanya gangguan psikologi pada ibu, baik saat pandemi maupun tidak. Selain faktor kerentanan terhadap penularan virus, kondisi kesehatan mental ini dapat diperburuk oleh kurangnya dukungan keluarga secara langsung dan dukungan sosial selama kehamilan, persalinan, dan periode postpartum. Walaupun keadaan pandemi dan pemberlakuan skrining kepada ibu hamil diketahui dapat mempengaruhi kondisi mental ibu, namun belum banyak laporan atau literasi yang melaporkan hubungannya secara rinci. Wanita yang dalam masa kehamilan merupakan kelompok yang rentan mengalami gangguan psikologi, termasuk gangguan kecemasan. Jurnal Penelitian Kesehatan STIKes Dharma Husada Bandung
Adanya pandemi seperti ini dapat menjadi faktor risiko yang memengaruhi terjadinya peningkatan kecemasan pada wanita hamil. ${ }^{11}$

\section{METODOLOGI PENELITIAN}

Penelitian ini menggunakan metode penelitian survey analitik pendekatan cross sectional, hal ini bertujuan untuk melihat dua variabel atau lebih tanpa adanya perlakuan atau intervensi dimana pengukurannya dilakukan pada satu waktu. Sampel yang digunakan penelitian ini adalah ibu hamil trimester III yang ada di PMB sebanyak 40 ibu hamil. Teknik pengambilan sampel dengan purposive sampling yang memenuhi kriteria inklusi dan eksklusi. Instrumen penelitian ini menggunakan kuesioner Hamilton Anxiety Rating Scale (HARS). Penelitian dilakukan pada bulan maret- mei 2021 di PMB Bidan R Kabupaten Bandung

\section{HASIL PENELITIAN}

\section{A. HASIL}

Tabel 1. Karakteristik Responden Ibu Hamil Trimester III

\begin{tabular}{llcc}
\hline No & Karakteristik & Frekuensi & Persentase \\
\cline { 3 - 4 } & & F & $\%$ \\
\hline $\mathbf{1}$ & Umur & & \\
& 21-25 tahun & 34 & 85,0 \\
& 26-30 tahun & 6 & 15,0 \\
& 31-35 tahun & 0 & 0,0 \\
& $>36$ tahun & 0 & 0,0 \\
\hline \multicolumn{2}{l}{ Total } & 40 & 100,0 \\
\hline $\mathbf{2}$ & Pendidikan & & \\
& SD & 0 & 0,0 \\
& SMP & 0 & 0,0 \\
& SMA & 29 & 72,5 \\
& PT & 11 & 27,5 \\
& Total & 40 & 100,0 \\
\hline
\end{tabular}




\begin{tabular}{llcc}
\hline $3 \quad$ Pekerjaan & & \\
& IRT & 23 & 57,7 \\
& Pegawai Swasta & 12 & 30,0 \\
& PNS & 2 & 5,0 \\
& Wiraswasta & 1 & 2,0 \\
& Lain-Lain & 2 & 5,0 \\
& Total & 40 & 100,0 \\
\hline $\mathbf{4}$ & Paritas & & \\
& Primigravida & 26 & 65,0 \\
& Multigravida & 14 & 35,0 \\
& Total & 40 & 100,0 \\
&
\end{tabular}

Berdasarkan tabel 1 menunjukkan bahwa umur responden yang paling banyak berusia $21-25$ tahun $(85,0 \%)$, berdasarkan karakteristik pendidikan menunjukkan bahwa ibu hamil yang memiliki pendidikan terakhir SMA $(72,5 \%)$, berdasarkan karakteristik pekerjaan sebagian besar ibu hamil menunjukkan bahwa sebagian besar memiliki pekerjaan sebagai IRT $(57,5 \%)$, dan berdasarkan karakteristik paritas menunjukkan bahwa sebagian besar ibu primigravida $(65,0 \%)$.

Tabel 1. Kecemasan Ibu Hamil Trimester III

\begin{tabular}{llll}
\hline No & Tingkat & Frekuensi & Presentase \\
\hline 1 & Tidak cemas & 3 & 7,5 \\
\hline 2 & $\begin{array}{l}\text { Kecemasan } \\
\text { ringan }\end{array}$ & 29 & 72,5 \\
\hline 3 & $\begin{array}{l}\text { Kecemasan } \\
\text { sedang }\end{array}$ & 6 & 15,0 \\
\hline 4 & $\begin{array}{l}\text { Kecemasan } \\
\text { berat }\end{array}$ & 2 & 5,0 \\
\hline & Jumlah & $\mathbf{4 0}$ & $\mathbf{1 0 0 , 0}$ \\
\hline
\end{tabular}

Berdasarkan tabel 2 sebagian ibu hamil menunjukkan bahwa ibu hamil yang merasakan kecemasan ringan sebanyak $72,5 \%$.
Tabel 2. Kesiapan Ibu Hamil Trimester III dalam Menghadapi Persalinan

\begin{tabular}{llll}
\hline No & Kesiapan & Frekuensi & Presentase \\
\hline 1 & Baik & 34 & 85.0 \\
2 & Cukup & 6 & 15,0 \\
3 & Kurang & 0 & 0 \\
\hline & Jumlah & 40 & 100,0 \\
\hline
\end{tabular}

Berdasarkan tabel 3 menunjukkan bahwa ibu hamil banyak yang merasakan siap menghadapi persalinan sebanyak $85,0 \%$.

\section{Tabel 3 Hubungan Tingkat Kecemasan Ibu Hamil Trimester III dengan Kesiapan menghadapi Persalinan di Masa Pandemi.}

\begin{tabular}{llc}
\hline kecemasan ibu hamil $^{*}$ & $X^{2}$ & Nilai p \\
\hline $\begin{array}{l}\text { kesiapan dalam } \\
\text { menghadapi persalinan }\end{array}$ & $12,955^{a}$ & 0,005 \\
\hline \begin{tabular}{l} 
Chi-Square Tests \\
\hline
\end{tabular} & & \\
\hline
\end{tabular}

Tabel 4 menunjukan hasil analisa data dengan uji chi square didapatkan nilai significancy 0.005. Nilai $\mathrm{p}<0.05$ dapat diambil kesimpulan bahwa terdapat hubungan antara tingkat kecemasan ibu hamil trimester III dengan kesiapan menghadapi persalinan di masa Pandemi Covid 19"

\section{B. PEMBAHASAN}

\section{a. Kecemasan Ibu Hamil Trimester III}

Hasil penelitian yang dilakukan menunjukkan bahwa dari 40 responden terdapat $29 \mathrm{ibu}(70 \%)$ yang merasakan kecemasan ringan, 3 ibu hamil yang tidak merasakan cemas, 6 ibu hamil mengalami cemas sedang dan 2 ibu hamil mengalami cemas berat. Dari distribusi ini dapat disimpulkan bahwa ibu hamil trimester III yang melakukan pemeriksaan di BPM Bidan 
$\mathrm{R}$ banyak ibu mengalami kecemasan ringan dalam menghadapi persalinan di masa pandemi dikarenakan responden memiliki kesempatan yang lebih banyak mendapatkan informasi dan konseling dari bidan tentang persiapan persalinan sehingga mengurangi tingkat kecemasan menghadapi persalinan. Sedangkan untuk 6 ibu hamil mengalami cemas sedang dan 2 ibu hamil mengalami cemas berat disebabkan oleh kurangnya pengetahuan dan informasi dari bidan sehingga ibu mengalami kecemasan untuk menghadapi persalinan.

Kecemasan pada ibu hamil dapat dipengaruhi oleh beberapa faktor seperti: usia, paritas dan latar belakang pendidikan dan pendidikan kesehatan. Semakin banyak ibu mendapatkan informasi tentang kesehatan selama hamil di masa pandemic covid 19, ibu merasa lebih tenang dalam menghadapi proses persalinan.

\section{b. Kesiapan Ibu Hamil Trimester III dalam Menghadapi Persalinan}

Hasil penelitian menemukan bahwa hampir $85 \%$ responden, ibu hamil di BPM Bidan R sudah siap menghadapi persalinan di masa pandemi ini dilihat ibu hamil sudah mendapatkan informasi yang cukup mengenai persiapan persalinan dan kesehatan ibu dan anak. Sedangkan 6 respondennya lagi belum cukup siap menghadapi persalinan di masa pandemi ini di karenakan adanya rasa takut dan kurangnya dukungan dari keluarga.
Ibu hamil yang tidak siap menghadapi persalinan dan tidak merencanakan persalinan mempunyai risiko untuk mengalami komplikasi dan kegawatdaruratan selama proses persalinan. Tiga terlalu dan empat terlambat merupakan faktor penyebab komplikasi dan kegawatdaruratan pada ibu hamil yang sebenarnya dapat dicegah dengan perencanaan persalinan yang baik, 3 Terlambat yaitu terlambat mengambil keputusan di tingkat keluarga, terlambat merujuk/ transportasi dan terlambat menangani dan 4 Terlalu yaitu melahirkan terlalu muda (dibawah 20 tahun), terlalu tua (diatas 35 tahun), terlalu dekat (jarak melahirkan kurang dari 2 tahun) dan terlalu banyak (lebih dari 4 kali). Pencegahan risiko yang lebih berbahaya bagi ibu hamil dan janinnya perlu dilakukan dengan meningkatkan informasi yang lebih dari bidan. Tujuannya untuk membantu ibu mempersiapkan persalinan sesuai dengan kebutuhan ibu dan bayi, agar proses persalinan berjalan dengan aman, sehat, lancar, dan terhindar dari komplikasi. ${ }^{12}$

Kesiapan persalinan dan penanganan komplikasi adalah proses perencanaan untuk persalinan normal dan antisipasi tindakan yang diperlukan dalam keadaan darurat (Hailu et al, 2011). Menurut Yenly ada hubungan antara usia ibu hamil dan jumlah pendapatan keluarga dengan kesiapan mental dalam menghadapi persalinan yang ditinjau dari tingkat kecemasan ibu. Dalam 
penelitian ini menunjukan bahwa frekuensi ANC yang teratur tidak menjamin ibu siap dalam menghadapi persalinan. Begitu pula dengan tingkat pendidikan belum tentu menghilangkan kecemasan dalam menghadapi persalinan. Penelitian Gebre, Gebremariam dan Abebe (2015) menunjukan bahwa kesiapan kelahiran berhubungan dengan ibu yang mendapat informasi dari layanan antenatal, memiliki pengetahuan minimal dua tanda bahaya selama kehamilan. $^{13}$

\section{c. Hubungan Kecemasan Ibu Hamil Trimester III dengan kesiapan menghadapi Persalinan pada masa pandemic covid 19}

Berdasarkan tabel 4 antara tingkat kecemasan ibu hamil dengan kesiapan dalam menghadapi persalinan menunjukkan mayoritas responden yang mengalami cemas ringan dan cemas sedang memiliki persiapan yang baik dalam menghadapi persalinan. Namun responden yang memiliki pengetahuan yang baik cenderung memiliki kecemasan yang ringan. Menunjukkan bahwa ada hubungan antara kedua variabel, sebanyak 25 responden $(86,2 \%)$ mempunyai kategori cemas ringan dan memiliki tingkat kesiapan menghadapi persalinan baik. Hasil uji chi-square menunjukkan nilai value sebesar 0,005. Berdasarkan nilai tersebut karena nilai value $<0.05$ dapat diambil kesimpulan bahwa "Tingkat Kecemasan Ibu Hamil Trimester III Berhubungan Dengan
Kesiapan Menghadapi Persalinan Di Masa Pandemi".

Data WHO (2010) menunjukkan sekitar 5\% wanita tidak hamil mengalami kecemasan, 8-10\% selama kehamilan, dan meningkat menjadi $13 \%$ ketika menjelang persalinan. Studi lain mengungkapkan bahwa terdapat $67 \%$ ibu hamil menyatakan agak cemas menjelang persalinannya, 12\% sangat cemas dan sisanya $23 \%$ menyatakan tidak cemas (Artanty, 2011). Sebagian besar wanita yang belum pernah melahirkan menyatakan cemas menghadapi persalinan. ${ }^{14}$

Kehamilan adalah perjalanan yang mengubah hidup dengan sendirinya, bahkan ketika pandemi melanda dunia Kecemasan pada ibu hamil dapat berpengaruh pada kesehatan ibu dan janin. Pandemi covid-19 sebagai salah satu pengaruh kecemasan ibu dalam menghadapi persalinan sehingga bisa menyebabakan ibu tidak siap untuk menghadapi persalinan jika ibu kurangnya pengetahuan. Bidan harus mampu meningkatkan pengetahuan ibu hamil tentang persiapan mental tentang menghadapi persalinan di masa pandemic covid-19. ${ }^{15}$ Agar proses persalinan nanti berjalan lancar, rencanakan baik-baik persiapan melahirkan sejak memasuki pertengahan trimester ketiga. Ibu hamil juga bisa mulai menyiapkan barang-barang yang perlu dibawa ke rumah sakit. Persiapan yang harus ibu siapkan di masa pandemi adalah proteksi diri dengan perlindungan diri seperti mencuci tangan, tidak keluar rumah 
kecuali hal mendesak, Melakukan physical distancing, menggunakan masker, dan menjaga jarak dengan orang sakit, Selain itu, jaga daya tahan tubuh dengan mengonsumsi makanan bergizi, berolahraga secara rutin, dan tidur yang cukup. Minumlah suplemen kehamilan sesuai anjuran bidan atau dokter. Memilih tempat melahirkan yang Tepat pilih rumah sakit atau klinik yang menerapkan prosedur melahirkan saat covid-19 yang tertib agar potensi penularan tidak terjadi. Pastikan kendaraan telah tersedia, baik pribadi maupun ambulans rumah sakit jika sewaktu-waktu Ibu hendak melahirkan. Berdiskusi dengan bidan mengenai metode melahirkan apakah Ibu akan melahirkan secara caesar atau normal. sebaiknya sudah didiskusikan menjelang persalinan. Sebaiknya tetap ikuti saran bidan demi keselamatan ibu dan bayi. Mempersiapkan mental atas segala kemungkinan ibu juga harus mempersiapkan mental atas segala kemungkinan yang akan terjadi. Termasuk jika ibu memiliki gejala yang mengarah ke covid-19. Hasil penelitian sebelumnya juga ibu hamil trimester III sudah siap untuk menghadapi persalinan namun masih merasakan sedikit cemas yang disebabkan oleh pandemi covid-19. ${ }^{16}$

Kecemasan menjelang persalinan yang dikarenakan takut pada proses persalinan sangat berpengaruh pada fungsi tubuh ibu saat bersalin. Kecemasan menyebabkan vasokontriksi sehingga aliran darah terhambat dan berkurang.
Vasokontriksi akan mempengaruhi organorgan yang terlibat pada proses persalinan menjadi tidak dapat berfungsi dengan baik. Tenaga mengedan menjadi kurang kuat, dorongan dari dalam tubuh pun tidak kuat, sehingga persalinan terhambat. ${ }^{14}$

\section{KESIMPULAN}

Masa pandemic Covid 19 merupakan hal yang dikhawatirkan ibu hamil menjelang proses persalinan, karena terdapat beberapa perubahan sistem yang menjadikan ibu hamil takut datang ke pelayanan kesehatan. Oleh karena itu sangat penting ibu hamil untuk diberikan edukasi tentang persiapan persalinan sehingga dapat mengurangi kecemasan pada kehamilan trimester III.

Diharapkan setiap tenaga kesehatan khususnya bidan untuk tetap memberikan konseling kepada ibu hamil trimester III tentang menghadapi persalinan di masa pandemi agar ibu hamil tidak mengalami kecemasan yang berlebihan dan siap menghadapi persalinan.

\section{DAFTAR PUSTAKA}

1. Annisa, D. F. \& Ifdil, I. Konsep Kecemasan (Anxiety) pada Lanjut Usia (Lansia). Konselor 5, 93 (2016).

2. Sembiring, E. Hubungan Dukungan Keluarga Dengan Tingkat Kecemasan Pasien Yang Akan Menjalani Preoperasi Kateterisasi Jantung Di Rsup H Adam Malik Medan. J. Mutiara Ners 2, 203209 (2019).

3. Aniroh, U. \& Fatimah, R. F. Tingkat Kecemasan Ibu Primigravida dalam Menghadapi Persalinan Ditinjau dari 
Usia Ibu dan Sosial Ekonomi. J. Ilmu Keperawatan Matern. 2, 1 (2019).

4. Puspitasari, I. \& Wahyuntari, E. Gambaran Kecemasan Ibu Hamil Trimester III. Proceeding of The URECOL 116-120 (2020).

5. Syafrie, I. R. Gambaran Pengetahuan Dan Kecemasan Ibu Hamil Trimester Iii Dalam Menghadapi Persalinan Di Wilayah Kerja Puskesmas Muara Aman Kecamatan Lebongâ Utara, Kabupaten Lebong Tahun 2016. J. Midwifery 5, 1-8 (2018).

6. Shodiqoh, Roisa, E., Syahrul \& Fahriani. Perbedaan Tingkat Kecemasan Dalam Menghadapi Persalinan Antara Primigravida dan Multigravida. J. Berk. Epidemiol. 2, 141-150 (2014).

7. Solikhah, F. K. \& Ernawati, N. Pengaruh pemberian health coaching berbasis health promotion model (nola j.pender) terhadap tingkat kecemasan ibu hamil di puskesmas dinoyo. J. Nurs. Care Biomol. 4, 96-103 (2019).

8. Fita Romalasari, N. \& Astuti, K. Hubungan Antara Dukungan Suami Dan Partisipasi Mengikuti Kelas Ibu Hamil Dengan Kecemasan Menghadapi Persalinan Pada Ibu Hamil Primigravida Trimester Tiga Di Puskesmas Nglipar Ii. G-Couns J. Bimbing. dan Konseling 4, 304-318 (2020).

9. Siregar, N. Y. et al. Tingkat Kecemasan Ibu Hamil Trimester III dalam Menghadapi Persalinan. J. Bidan Cerdas 3, 18-24 (2021).

10. Dewi, R., Widowati, R. \& Indrayani, T. Pengetahuan dan Sikap Ibu Hamil Trimester III terhadap Pencegahan Covid-19. Heal. Inf. J. Penelit. 12, 131-141 (2020).
11. Rahmadani, R. Faktor-Faktor yang Berhubungan dengan Kesiapan Persalinan di Puskesmas Banguntapan II Bantul Yogyakarta. Naskah Publ. 1, 1-13 (2017).

12. H, P. S., Hapsari, D., Dharmayanti, I. \& Kusumawardani, N. Faktor-Faktor Yang Berpengaruh Terhadap Risiko Kehamilan "4 Terlalu (4-T)" Pada Wanita Usia 10-59 Tahun (Analisis Riskesdas 2010). Media Penelit. dan Pengemb. Kesehat. 24, 143-152 (2015).

13. Gitanurani, Y. Faktor-Faktor Yang Berhubungan Dengan Kesiapan Persalinan di Puskesmas Jetis I Bantul Yogyakarta. Keperawatan Matern. (2017).

14. Husna, D. A., Studi, P., Bidan, P., Kedokteran, F. \& Airlangga, U. DIFFERENCE LEVEL OF ANXIETY ABOUT FACING DELIVERY BETWEEN NULLIPAROUS AND MULTIPAROUS PREGNANT WOHusna, D. A., Studi, P., Bidan, P., Kedokteran, F., \& Airlangga, U. (2013). DIFFERENCE LEVEL OF ANXIETY ABOUT FACING DELIVERY BETWEEN NULLIPAROUS AND MULTIPAR. 50-61 (2013)

15. Ahmad, M., Usman, A. N., Arifuddin, S. \& Patmahwati, P. Persiapan Persalinan dan Kelahiran Di Masa Pandemi COVID-19. J. Pengabdi. Masy. Indones. 1, 109-113 (2021).

16. Zulfiana, E., Cikmah, A. M. \& Latifah, U. Peningkatan Pengetahuan Tentang Kesiapan Mental Pada Ibu Hamil Menghadapi Persalinan Saat Pandemi Covid-19 di Posyandu. JPM J. Pengabdi. Masy. 1, 75-77 (2021) 